\title{
Kolyma 1992
}

Rytyytämme venäläisen (itäsiperialaisen) kuun alla venäläistä (itäsiperialaista) hiekkatietä lähes jousettoman GAZ-kuorma-auton lavakopissa kohti UstjOmtsukia. Tämä koettelee selkälihaksia, mutta on silti lähes lepoa (muutamat yrittävät jopa nukkua): hetki sitten onnuimme lavakoppiautollamme alas tulvien uurtamaa ja hevosenpään kokoisten irtokivien pohjustamaa Butugytsagin tietä NKP:n Ustj-Omtsukin piirin entisen ensimmäisen sihteerin Gennadij G:n pitäessä tunnelmaa yllä kertomalla kalajuttuja.

Palaamme Butugytsagin leiriltä. Oppaamme Gennadij G. hahmotteli retkipäiväkirjaamme sen kartan. "Nizhnyi Butugytsag", leirin alin osa, oli Terrasovyi-joen laaksossa harvaa lehtikuusimetsää kasvavalla alangolla. Täällä oli leirin infrastruktuuri kuten sähkölaitos, varastot ja korjaamot. Alaleirin parakit olivat puisia eikä niistä enää ole näkyvissä kuin kuloheinän peittämiä kumpuja.

Noin seitsemän kilometriä ylävirtaan yhdytämme Besin sivujoen. Laakso on jo kaventunut, ja sen pohja kohoaa muutaman kymmenen asteen kulmassa kohti vuorten huippuja. Joet ovat sydänkesällä kutistuneet puroiksi. Tässä oli uraanirikastamo; uraanimalmi louhittiin sivummalta Bes-joen laaksosta. Tri B. käy mittaamassa rikastamorakennuksen radioaktiivisuuden. Taustasäteilyä ei ole sen enempää kuin ympäristössä, mutta entisen rikastamon pihalla on muutamia ruostuneita, voimakkaasti säteileviä tynnyreitä.

Jatkamme puronotkoa ylöspäin laakson ylimmälle tasanteelle, joka on juuri puurajan tuntumassa, selvästi metsärajan yläpuolella. Tasanteen ympärille kiertyvät vuorenhuippujen kaljut rakkarinteet. Puron varressa kasvaa kurjaa lepikkoa. Tässä oli "Verhnyi Butugytsag", yläleiri. Parakit ovat jäljellä, koska ne on rakennettu kivestä: puolimetriset seinät, kalterit ikkunoissa, ympäristö täynnä ruostuneita piikkilankoja.

Leiri ei lopu tähän. Jatkamme muutamia kilometrejä toisen sivujoen, Shaitanin, vartta ylöspäin, loppumatkan kuusikymmenasteista louhikkorinnettä kontaten. Vuoriston huipulla, noin 1500 metrin korkeudessa on "Gornjak", leirin tinakaivos. Harjanteella ammottaa useita suuria kaivoskuiluja. Takainen rinne on kaivuujälkien rikkoma kuin keväinen myyräpelto. Kaikkialla lojuu ruostuneita ratakiskoja, vinttureita, vaijerin pätkiä, lapion teriä, kaivoslamppujen kehikoita, roinaa. Tinamalmin rikastamo "Karmen" oli vastakkaisella alarinteellä, huipulta käsin näkymättömissä.

Myös Gornjakin asuinparakit on rakennettu kivestä: puolen metrin paksuisia seiniä vuoren laella törröttämässä, kalterit ikkunoissa. Tunnistamme vartijoiden asumukset siitä, että ne on ympäröity moninkertaisella piikkilangalla. Vankien karkaaminen ei ollut Gornjakissa ongelma, vartijoiden ja ruokavarastojen suojaaminen sen sijaan oli.

Täällä on lunta 10 kuukautta vuodessa. Täällä tuulee aina. Miten mahtoi sujua eläminen umpikivestä rakennetuissa kopeissa 40 asteen pakkasessa? Toiko joku vankien asumuksiin polttopuita? Mistä?

Gennadij G:n tietämän mukaan Butugytsag oli asuttu 30-luvun lopulta 50luvun puoliväliin. Vankeja oli kerrallaan lähes 10000 . Tri B. esitti tinakaivok- 
sella yläleirissä työskennelleiden eliniästä seuraavat arviot: syksyllä tuoduista vangeista valtaosa menehtyi neljän kuukauden kuluessa saapumisestaan. Keväällä tuodut elivät yleensä kesän yli ja ehtivät tänä aikana hiukan sopeutua vuoriston talven käsittämättömän kammottaviin olosuhteisiin, mutta hengissä Butugytsagista selvisivät vain ne jotka välttivät yläleirin ja kaivoksen.

\section{$* * *$}

Butugytsag oli yksi Kolyman hirvittävimmistä leireistä. Kolyma oli Neuvostoliiton leirimaailman hirvittävin alue.

Kolyma on itäisin Jäämereen laskevista Vanhan maailman suurista joista. Sen itäpuolella ovat ennen Beringin salmea ja Alaskaa enää Tsuktsien niemimaa sekä Tyyneen valtamereen laskeva Anadyr. Kolyman valuma-alue käsittää Suomen kokoisen alueen suota, heikkokasvuista lehtikuusitaigaa sekä vuoristoa, jonka korkeimmat huiput joen latvoilla lähellä Ohotan meren rannikkoa ovat 2500 metrin korkuisia. Koko alue on paksun ikiroudan maata.

Kolyman leirisaariston kehityskaari on tunnettu. Hrustshevin kaudella julkaistiin jopa Neuvostoliitossa joitakin Kolymalta selviytyneiden muistelmia, lännessä muutamia muita. Robert Conquest esittää näihin nojautuvan yhteevedon teoksessaan Kolyma. The Arctic Death Camps (MacMillan, 1978). Myös Solzhenitsynin Gulag esittelee Kolymaa, joskin sen päämateriaali on peräisin muilta alueilta.

Kolyman moottori oli 'Dalstroj", vuonna 1931 Siperian itäisimmän kolkan kehittämiseksi perustettu, suoraan salaiselle poliisille NKVD:lle alistettu organisaatio. Dalstroj'n sysäsi käyntiin kulta, jonka ensimmäiset merkittävät esiintymät löydettiin 20-luvun loppuvuosina Ohotan mereen laskevista joista. Pian sen jälkeen kultaa löytyi myös Kolyman latvoilta. Itä-Siperia oli kuitenkin 20-luvulla hyvin harvaan asuttua, ja vähäinen venäläisväestö asui lähinnä Tsukotkan rannikon kauppakeskuksissa. Dalstroj käytti vankileireille koottua orjatyövoimaa. Jo tsaarinvallan aikana oli oivallettu, että vangit ratkaisevat asumattomien alueiden työvoimaongelman. Neuvostoliitossa tämä oivallus muuttui laajaksi käytännöksi 20-luvun loppuvuosina (Solzhenitsyn, Gulag, 2. osa).

Alkuvuosien olot Kolyman leireillä olivat ilmeisesti suhteellisen siedettävät. Ankarat luonnonolot eivät murra ihmistä, jonka ravinto, vaatetus ja työtaakka ovat kohtuullisia. Mutta vuosina 1937-38 Dalstroj'n ja leirien alkuvaiheen johtajat teloitettiin ja tilalle nimitettiin uudet. Kolyman johtoajatukseksi tuli taloudellisen tuotoksen sijasta vankien tuhoaminen. Työnormit kiristettiin täysin mielettömiksi samalla kun ruoan ja vaatetuksen laatua heikennettiin olennaisesti. Robert Conquestin arvio Kolyman uhrien kokonaismääräksi on kolme miljoonaa. Samanlaisista arvioista puhuimme Butugytsagissa Gennadij G:n kanssa. 
mässä erämaata", kuten retken työnimi oli ilmaistu: luotaamassa koskemattoman ja taltuttamattoman luonnon kulttuurisia merkityksiä modernissa maailmassa. Miten Stalinin Neuvostoliiton tuhoamisleiri liittyy erämaan etsintään?

Tri B. ilmaisi tämän suunnilleen seuraavin sanoin: "Ei ole ihme, että Kolymalla ei kukaan välitä luonnosta ja sen suojelusta kun Kolymalla ei ole koskaan välitetty ihmisestä."

Kulttuurin luontosuhteen ensimmäinen ja tärkein määrittäjä on kulttuurin suhde ihmiseen. Tuhoamisleirit ovat Itä-Siperian luonnon kulttuuristen määritysten prisma.

Koen saman seistessäni Gornjakin kaivoksen vuorenharjanteella elokuun pilvettömänä korkeapainepäivänä. Joka suunnassa utuun häviävien vuorenhuippujen jono, kalliokeilojen rinteet tummanharmaata, roudan rikkomaa, kasvitonta rakkaa. Tämä on komeimpia maisemia mitä olen koskaan kuvitellut näkeväni. Onko sitä mahdollista katsoa muistamatta niitä tuhansia, kymmeniätuhansia silmäpareja, jotka olivat täällä ennen meitä? Mitä ne näkivät katsoessaan tätä maisemaa?

Butugytsag on täydellisesti ulkopuolella sen, mitä olimme pitäneet mahdollisena. Tajusimme käynnin Butugytsagissa vasta jälkikäteen. Palatessamme Magadanista Moskovaan kone lensi alkumatkan ensimmäiset tunnit Itä-Siperian ja Jakutian vuoristojen yllä. Samanlaisia harjanteita kuin Gornjak, loputtomiin...

Magadanin museossa avattiin vierailumme aikana leirimaailmaa kuvaava näyttely, jonka esineistöön sisältyi 50-luvulla painettu Neuvostoliiton taloudellinen kartta. Butugytsag oli merkitty karttaan: symbolien mukaan siellä sijaitsi sähkölaitos ja kaivos. Epäilemättä sijaitsi. Lähes kaksikymmentä vuotta Solzhenitsynin Gulagin ilmestymisen jälkeen on tietenkin naiivia järkyttyä siitä, että 50-luvulla painettuun Neuvostoliiton karttaan on merkitty vankileiri kansantalouden saavutuksena. Järkytyin silti. Ja vasta sen jälkeen ymmärsin tälle käänteisen kysymyksen koko merkityksen: paljonko Neuvostoliitossa oli sellaisia kansantalouden saavutuksia, jotka eivät olleet vankileirejä?

Keskustelimme tri B:n kanssa leirien tuottamasta moraalisesta järkytyksestä. Hän on itse kokenut sen jo vuosia sitten. Kuten B. totesi, jokainen leiriterroriin johtanut yksittäinen askel ja toimenpide on loogisesti ymmärrettävissä jos lähtökohta, itseään puolustavan vallankumouksellisen diktatuurin oikeutus, hyväksytään. - Mutta juuri diktatuurin sokea oikeutus on käsittämätön. Siksi säilyy käsittämättömänä, että kokonaisen mantereen halvaannuttanut terrorijärjestelmä saattoi syntyä. Kaikki terrorin taustaan liittyvät kysymykset on pakko kysyä.

Eräs ilmeinen Neuvostoliiton leirimaailman ratkaisematon moraalinen ongelma on järjestelmän kehittäjien ja ylläpitäjien myöhempi kohtalo. Yritimme perätä tätä Gennadij G:Itä, mutta hän vastasi yksioikoisesti, että leirien vartijat suorittivat normaaleja yhteiskunnallisia tehtäviä, esimerkiksi asevelvollisuutta. 
Itä-Siperian moderni tuotannollinen perusta on rakennettu kokonaisuudessaan vankileirein. Retkemme pääkohde oli Tsukotkan Jäämeren puoleisessa kainalossa sijaitseva Tsaunin biologinen asema. Käsiimme osui 50-luvulla painettu alueen kartta, jossa näkyvät satamakaupunki "Pevek" (alunperin leiri) sekä siitä noin 70 kilometrin päässä sisämaassa oleva usean toimipisteen kaivoskompleksi "Krasnoarmeiskoje" (alunperin leiri). Näitä yhdistää toisiinsa parinsadan kilometrin mittainen maantieverkko. Karttaan on teiden varteen merkitty kahdeksan paikkakuntaa nimeltään "Parakit nn km" ( $\mathrm{nn}=21,24,26,33$, $42,47,60,65)$. Nämä olivat tien rakentamisesta ja hoidosta vastanneet leirit, merkittyinä omalla nimellään karttaan.

Moraalisen kauhistuttavuutensa ohella Itä-Siperian leirihistorialla on myös käytännöllisempi ulottuvuus: orjatyöhön perustuvien taloudellisten toimien kannattavuudesta ei ole mahdollista muodostaa mitään realistista käsitystä. Tältä muutaman Suomen kokoiselta ja periaatteessa hyvin rikkaalta alueelta ei siis ole koko Dalstroj'n kaudelta, 30-luvun alusta 50-luvun lopulle, mitään järkeviä taloudellisia laskelmia.

Dalstroj'n purkauduttua Kolyman työvoiman turvasivat Komsomolin iskurityöläiset. Alueen talous perustui keskusvallan mahtaviin subventioihin kun taas arvokkaimmat tuotteet, erityisesti kulta, hävisivät viimeistä hippusta myöten suoraan Moskovaan. Ei siis vieläkään mitään laskelmia toimintojen todellisesta taloudellisesta kannattavuudesta. Voi olla, että Neuvostoliiton keskusalueilla yritysten toiminnan tosiasiallisena taustana ja normien luojana olivat moninaisten neuvottelu- ja sopimusverkostojen luomat eräänlaiset markkinat, kuten Pekka Sutela on esittänyt ( $t \& e$ 2/1992). Strategisesti tärkeään kaivostoimintaan keskittyneisiin laita-alueisiin tämä tulkinta tuskin kuitenkaan pätee.

Reaalisen taloudellisen perustan puuttuminen on Itä-Siperiassa valtava ongelma. Magadan on Tampereen kokoinen kaupunki vailla itsenäistä tuotannollista perustaa, keskitysleirien verkoston hallinnolliseksi keskukseksi syntynyt. Nyt, subventioiden loputtua, väki muuttaa joukoittain Magadanista Venäjän rintamaille. Itä-Siperian pienemmistä yhdyskunnista muutetaan joukoittain Magadaniin (ja pian edelleen pidemmälle etelään?). Magadanissa ei ole merkkiäkään siitä oma-aloitteisuuden noususta, joka näkyy maakylissä toisella kokemuspiiriini sisältyvällä Venäjän syrjäalueella, Uralin kupeessa Komissa. Ero on helppo ymmärtää, koska Komissa on itsenäisen taloudellisen toiminnan mahdollistavia perinteitä, Magadanissa ei. Miten käy Magadanin?

Kolyman moraalinen ja taloudellinen perintö on ankaraa todellisuutta. Taakka on aivan liian raskas voidakseen jäädä venäläisten yksityisasiaksi. Emme vielä ymmärrä, miten voimme hyödyllisesti osallistua tämän vararikon selvittämiseen. On kuitenkin hyvä muistaa, että Neuvostoliiton tuottanut historia on myös meidän historiaamme vähintään yhtä läheisesti kuin fasistisen Saksan tuottanut historia. 